\title{
Efficacy of Imidacloprid in the Control of Thaumastocoris peregrinus on Eucalyptus scoparia in Sydney, Australia
}

\author{
Ann E. Noack, Jyri Kaapro, Kathryn Bartimote-Aufflick, \\ Sarah Mansfield, and Harley A. Rose
}

\begin{abstract}
Thaumastocoris peregrinus, an Australian native, is a new and serious pest of urban eucalypts planted in Sydney and commercial centers of Australia. In recent years, it has spread to and attained pest status in South African Eucalyptus plantations and, more recently, has been discovered in Argentina and Uruguay. Mature Eucalyptus scoparia street trees, growing in a southern Sydney suburb, were microinjected with imidacloprid at three concentrations and monitored for three years. The abundance of T. peregrinus on treated eucalypts declined significantly compared to untreated trees over this time. Further, at the lowest concentration of chemical this insect was effectively controlled for two years. Imidacloprid (SilvaShield ${ }^{\oplus}$; Bayer Environmental Science) has been registered in Australia for the control of T. peregrinus. Key Words. Eucalypt Pest; Imidacloprid; Systemic Insecticide; Thaumastocoris peregrinus; Thaumastocoridae.
\end{abstract}

Thaumastocoris peregrinus is a small sap-feeding insect in the family Thaumastocoridae (Hemiptera: Heteroptera). The family contains three subfamilies with disjunct distributions. Thaicorinae is known only from Thailand; its hosts are unknown. Xylastodorinae from South America lives exclusively on palms (Cassis et al. 1999) and following its introduction to Florida in 1920, became a significant pest on royal palms (Roystonea regia) (Reinert 1975). Thaumastocorinae is distributed throughout Australia (with a single specimen known from India) and its host plants are predominantly dicotyledons.

Until recently, the Australian group, Thaumastocorinae, was considered rare (Cassis et al. 1999). However, during the past eight years $T$. peregrinus has rapidly established as a pest of some Eucalyptus species throughout metropolitan Sydney and regional towns of New South Wales, Australia. It has also become a significant and rapidly spreading pest of eucalypt plantations in South Africa (Wingfield 2007) and urban plantings of eucalypts in Pretoria (pers. comm. Simon Lawson). More recently, it has become established on urban eucalypts growing in Buenos Aires, Argentina (Carpintero and Dellapé 2006). Some commercial plantations of the Entre Rios Province (Argentina) and Uruguay are also infested (pers. comm. Carlos Coviella).

Within Sydney, two Eucalyptus species-E. scoparia and E. nicholii-have been seriously impacted by $T$. peregrinus infestation. These trees are very common as street and garden trees within the metropolitan area and are valued for their compact stature and fast growth (Noack and Rose 2007). When heavily infested these trees display a reddening of leaves, and as the infestation progresses, the entire canopy turns reddish yellow and the tree drops its leaves (pers. obs. A. Noack). Significant numbers of eucalypts have been removed from the Sydney basin by local councils due to such infestations (pers. obs. A. Noack).

Two mymarid wasps have been confirmed attacking the eggs of T. peregrinus in Sydney; Cleruchoides noackae and St- ethynium sp. (Lin et al. 2007). Although mymarids are recognised as exerting significant natural control over a large number of taxa, only a few species have been used in deliberate control programs (Huber 1986; Lin et al. 2007). Research to determine the efficacy of these wasps in controlling $T$. peregrinus is in its infancy but until long-term sustainable management of this pest is achieved intervention with insecticides is one solution.

Imidacloprid is a chloronicotinyl insecticide that acts on the nicotinic acetylcholine receptor of invertebrates (Bai et al. 1991). It was released in the early 1990s and is regularly used to control insects in a variety of situations (Smith and Smith 2000; Webb et al. 2003; Ahern et al. 2005; Poland et al. 2006; Frank et al. 2007). The impact on nontarget insects by imidacloprid has been assessed as significantly less than many other insecticides (Albajes et al. 2003; Kilpatrick et al. 2005) and, although research in the mid 1990s implicated imidacloprid as associated with colony collapse in the honey bee (Apis mellifera), more recent research conflicts and advances numerous other causal factors (reviewed in Devine and Furlong 2007; Oldroyd 2007).

When used as a systemic, imidacloprid disperses evenly in young growing plants (Nauen et al. 1999) and trees (Lawson and Dahlsten 2003; Castle et al. 2005; Cowles et al. 2006) making it a popular and effective chemical against many hemipteran pests (Ahern et al. 2005) such as psyllids, adelgids, lace bugs, flatids, and aphids (Nauen 1995; Smith and Smith 2000; Young 2002; Szczepaniec and Raupp 2007). Imidacloprid has been used to control Thaumastocoridae. Howard and Stopek (1998) administered imidacloprid systemically, via a root drench, to control outbreak populations of royal palm bug (Xylastodoris luteolus) on royal palms in Florida and report at least three months of effective control.

Environmental concerns render the systemic use of pesticides more desirable than foliar application, particularly in urban settings where pesticide drift is an additional problem (Lawson and Dahlsten 2003). The inaccessibility of canopies of large trees com- 
bined with the low amounts of pesticides used in trunk injection makes this method of pest control attractive to stakeholders.

Additionally, there is a need to investigate the insecticide dosage required to maintain the desired level of control, as some stakeholders (public and private) will use this information for cost analysis when making decisions on the treatment of important or significant trees.

This paper reports the collaboration of Bayer Environmental Science Australia, the University of Sydney, and the Sutherland Shire Council in evaluating the efficacy of trunk injected imidacloprid for the control of $T$. peregrinus on an urban planting of E. scoparia.

\section{MATERIALS AND METHODS}

Mature E. scoparia trees growing along a residential street in Sutherland, a southern suburb of Sydney, Australia $\left(34^{\circ}\right.$ 01.653 'S; $151^{\circ} 04.014^{\prime} \mathrm{E}$; Alt. $89 \mathrm{~m}$ ) were utilized in this trial. These trees were planted in 1982 (pers. comm. Mark McCaughtrie) and are one of the dominant street trees in the area. Fourteen trees, situated on both sides of the street, ranging in height from approximately 10 to $30 \mathrm{~m}$ (30 to $100 \mathrm{ft}$ ) were selected for the trial. Trunk diameter was measured at breast height $(1.3 \mathrm{~m} / 51$ in aboveground level), and ranged in size from 380 to $810 \mathrm{~mm}$ (15 to $32 \mathrm{in}$ ). For the purposes of this study, trees were assigned to one of four groups; control (no treatment) or low, mid, and high treatment concentrations (Table 1).

Table 1. Tree size (diameter) and dose administered on 13th September 2004.

\begin{tabular}{lll}
\hline Tree group & $\begin{array}{l}\text { Diameter } \\
\text { cm (in) }\end{array}$ & $\begin{array}{c}\mathrm{g} \\
\text { imidacloprid/cm } \\
\text { (in) of } \mathrm{dbh}^{2}\end{array}$ \\
\hline control & $72(28)$ & 0 \\
control & $60(24)$ & 0 \\
control & $73(29)$ & 0 \\
low conc. & $81(32)$ & $0.05(0.004)$ \\
low conc. & $67(26)$ & $0.05(0.004)$ \\
low conc. & $67(26)$ & $0.04(0.003)$ \\
low conc. & $57(22)$ & $0.05(0.004)$ \\
mid conc. & $65(26)$ & $0.09(0.008)$ \\
mid conc. & $62(24)$ & $0.10(0.008)$ \\
mid conc. & $38(15)$ & $0.11(0.009)$ \\
mid conc. & $38(15)$ & $0.11(0.009)$ \\
high conc. & $65(26)$ & $0.15(0.012)$ \\
high conc. & $57(22)$ & $0.16(0.013)$ \\
high conc. & $51(20)$ & $0.16(0.012)$ \\
\hline z grams $($ oz) of active ingredient per cm of diameter at dbh $(1.3 \mathrm{~m} / 51 \mathrm{in})$.
\end{tabular}

A solution of $200 \mathrm{~g} / \mathrm{L} \quad(26.7 \quad \mathrm{oz} / \mathrm{gal})$ imidacloprid [SilvaShield ${ }^{\circledR}$ SL, 20\% (AI)] was administered with a Sidewind$\mathrm{er}^{\circledR}$ tree injector at $2400-2700 \mathrm{kPa}(350-400 \mathrm{psi})$. Holes were drilled approximately $40-50 \mathrm{~mm}$ (1.6-2.0 in) into the sap wood and distributed as evenly as possible around the circumference of the trunk at a height of approximately 1.0 to $1.5 \mathrm{~m}$ (3.2 to $4.9 \mathrm{ft})$.

Trees receiving the low concentration treatment received doses in $5 \mathrm{ml}(0.17 \mathrm{fl} \mathrm{oz})$ allotments, while the solution delivered to the mid and high concentrations groups was administered in $10 \mathrm{~mL}(0.34 \mathrm{fl} \mathrm{oz})$ doses.

Using a cherry picker, the canopies of treated and control trees were sampled for the presence of T. peregrinus on ten oc- casions over three years commencing September 15, 2004. Initially the trees were sampled on a monthly (approximately) basis and then at increasing intervals up to two years after treatment (at treatment and then, 1 month, 1.5 months, 3 months, 6 months, 9 months, 1 year, 1.5 years, and 2 years). A supplementary sample was conducted at three years post treatment.

A cherry picker operator manoeuvred the $23 \mathrm{~m}(75.5 \mathrm{ft})$ telescopic boom mounted on a 14 tonne (15.4 ton) truck over the accessible canopy of each tree. From the cherry picker bucket, the sampler removed one fully expanded leaf at approximately five second intervals until a total 40 leaves were taken from each tree. These leaves were bagged, labelled and taken back to the laboratory at The University of Sydney. In the laboratory the leaves were examined under a microscope and adult $T$. peregrinus were counted.

Raw data were $\log _{10}(x+1)$ transformed. The log transformation was necessary as the residuals for the raw count data did not fit the (classic) assumptions of the analysis of variance (ANOVA) and repeated measures residual maximum likelihood (REML) analysis such as constant variance and linearity. This log transformation provided a notable improvement in residual diagnosis. REML analysis, with an unstructured model for correlation within subject across time, was used to detect statistically significant differences in the efficacy of each treatment over time. The unstructured correlation model was chosen due to unequal spacing between time points. The test statistic (Wald/df, symbolised by $X^{2}$ ) used in this analysis is assumed to approximate the chi-square distribution. Post hoc comparisons between means were conducted by comparing the absolute mean difference to the least significant difference (LSD) (Patterson and Thompson 1971; McCulloch and Searle 2001).

\section{RESULTS AND DISCUSSION}

Efficacy results were based on the comparison of population levels of $T$. peregrinus on treated and untreated trees over the three years of this study. The repeated measures REML analysis showed significant effects of time $\left(P<0.001, X^{2}=\right.$ 204.53, df $=9)$, treatment $\left(P<0.001, X^{2}=1115.34\right.$, df $\left.=3\right)$ and a significant interaction between treatment and time $\left(P<0.001, X^{2}=180.83\right.$, df $\left.=27\right)$. Imidacloprid effectively controlled $T$. peregrinus within one month of application and

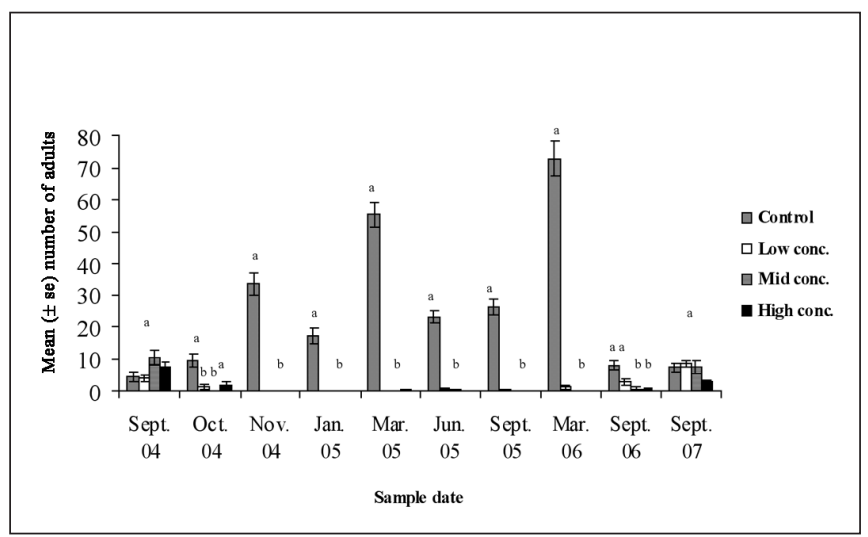

Figure 1. Abundance of Thaumastocoris peregrinus adults (per 40 leaves) on Eucalyptus scoparia trees over two years after treatment with three concentrations of imidacloprid. Within each sample point, means that share the same letter do not differ. Note time scale is not even. 
maintained adequate control for at least two years (Figure 1).

The initial sample established baseline populations for all treatments and confirmed there was no difference between any of the treatments at the beginning of the experiment. This sample was taken three days after administration of the imidacloprid and it would be unlikely the chemical would have been translocated throughout the tree in that time. However, by the next sampling date, one month post-treatment, there was a significant decline in the T. peregrinus populations on all treated trees. The mean numbers of insects sampled on low and mid concentration treatments were statistically less than those of the untreated trees. Trees treated with the high concentration, however, were not; but nonetheless their number had reduced considerably. By the third month, all treatments had significantly fewer insects than untreated trees and further, there was no difference in the control afforded by the different concentrations of imidacloprid. This trend was maintained for almost two years until September 2006. Sampling at this time indicated the efficacy of low concentration application had diminished. By the final sample, September of the following year, there was no significant difference between treatments and control. Although the trees were not surveyed between September 2006 and 2007, it is likely the control afforded by the high concentration application was impacting on T. peregrinus as their numbers were half that of any other group. Additionally, trees were visually monitored during this time and, although control and trees treated with the lower concentration of chemical displayed the characteristic reddening of the canopy, the trees in the high concentration group did not.

The longevity of control attained in this experiment is comparable with the work of Frank et al. (2007) and Szczepanic and Raupp (2007) who established that soil application of imidacloprid provided at least two years protection from Japanese beetles on little-leaf linden trees and hawthorn lace bugs on cotoneasters respectively.

While this study's results concur with the work of Cowles et al. (2006) in the longevity of control the chemical imidacloprid delivered, they conflict in the efficacy of the chemical delivery system. Investigating the efficacy of imidacloprid in controlling the hemlock woolly adelgid on hemlock trees these workers additionally compared the efficiencies of delivery method and found that, while the soil application of imidacloprid controlled these insects for two years, trunk injection of the chemical was ineffectual.

Cowles et al. (2006) compared the efficacy of three trunk injection protocols and three soil drench methods in controlling adelgids and analyzed imidacloprid residues in tree tissues from all treatments. In their own words the "precise relationship between residues and efficacy are elusive." This is demonstrated in an assay which determined concentration of imidacloprid in tissues from trunk injected trees was similar to that of the soil drench group, yet the control afforded by the former was ineffectual; and in another they found chemical residues in the tissues of trunk injected trees higher than the untreated which in turn was higher than the soil drench residues. Cowles et al. (2006) suggest possible reasons for the poor performance of trunk injection methods; there may have been an interaction between the hemlock sap and the injected formulation of imidacloprid which resulted in the active ingredient being precipitated out of the formulation by dilution of the solvent with sap or the chemical may have been unevenly translocated throughout the canopy.
Few investigations have been conducted on the control of insect pests by imidacloprid on eucalypt trees. This study's results compare favorably with those of Young (2002) who microinjected eucalypts with imidacloprid $[3 \mathrm{ml}$ of $10 \%$ (AI) per $5 \mathrm{~cm}$ ( 2 in) of trunk diameter] to control red gum lerp psyllid. In his study imidacloprid treated trees showed a significant reduction of psyllids for eight months. However, by the end of the experiment at 15 months, large variation in the control afforded by the treatment occurred between the trees. This worker observed that some trees had longer residual activity than others, and indicated several factors such as tree health, age, crown, and root structure may influence material uptake and distribution.

The results suggest a constant and even translocation of chemical throughout the treated trees as standard errors (variation) were small within all treatment groups. In this trial the longevity and efficacy of control afforded by imidacloprid can probably be attributed to a combination of the insect's susceptibility to the chemical, and to the use of multiple injection sites which ensured an even distribution of chemical throughout the tree.

\section{CONCLUSION}

Trees treated with imidacloprid [SilvaShield SL, 20\% (AI)] showed a significant reduction in populations of $T$. peregrinus when compared to untreated trees. The study authors suggest microinjection of this chemical at a rate of 3 to $5 \mathrm{ml} / 10 \mathrm{~cm}$ ( 0.10 to $0.17 \mathrm{fl} . \mathrm{oz} / 4 \mathrm{in})$ of dbh effectively controlled $T$. peregrinus for two to three years. SilvaShield has been recently registered for the control of $T$. peregrinus on eucalypts in Australia.

Acknowledgments. Bayer Environmental Science is acknowledged for supporting this project and the Christian Rowe Thornett Postgraduate Scholarship for supporting the first author. The authors thank Mark McCaughtrie and the Sutherland Shire Council for supporting this research. Also, thanks to Mark McCaughtrie's team for managing the traffic and keeping the authors safe. Geoff Eldridge, Sidewinder Tree Injectors, for injecting the trees. The residents of Waratah Street, Sutherland are thanked for their patience.

\section{LITERATURE CITED}

Ahern, R.G., S.D. Frank, and M.J. Raupp. 2005. Comparison of exclusion and imidacloprid for reduction of oviposition damage to young trees by periodical cicadas (Hemiptera: Cicadidae). Journal of Economic Entomology 98:2133-2136.

Albajes, R., C. López, and X. Pons. 2003. Predatory fauna in cornfields and response to imidacloprid seed treatment. Journal of Economic Entomology 96:1805-1813.

Bai, D., S.C.R. Lummis, W. Leicht, H. Breer, and D.B. Satelle. 1991. Actions of imidacloprid and related nitromethylene on cholinergic receptors of an identified insect motor neurone. Pesticide Science 33:197-204.

Carpintero, D.L., and P.M. Dellapé. 2006. A new species of Thaumastocoris Kirkaldy from Argentina (Heteroptera: Thaumastocoridae: Thaumastocorinae). Zootaxa 1228:61-68.

Cassis, G., R.T. Schuh, and H. Brailovsky. 1999. A review of Onymocoris (Heteroptera: Thaumastocoridae), with a new species, and notes on hosts and distributions of other thaumastocorid species. Acta Societatis Zoologicae Bohemoslovacae 63:19-36. 
Castle, S.J., F.J.Byrne, J.L. Bi., and N.C. Toscano. 2005. Spatial and temporal distribution of imidacloprid and thiamethoxam in citrus and impact on Homalodisca coagulata populations. Pest Management Science 61:75-84

Cowles, R.S., M.E. Montgomery, and C.A.S-J. Cheah. 2006. Activity and residues of imidacloprid applied to soil and tree trunks to control hemlock woolly adelgid (Hemiptera: Adelgidae) in forests. Journal of Economic Entomology 99:1258-1267.

Devine, G.J., and M.J. Furlong. 2007. Insecticide use: Contexts and ecological consequences. Agriculture and Human Values 24:281-306.

Frank, S., R. Ahern, and M.J. Raupp. 2007. Does imidacloprid reduce defoliation by Japanese beetles on linden for more than one growing season? Journal of Arboriculture 33:392-396.

Howard, F.W., and A. Stopek. 1998. Control of royal palm bug with imidacloprid. Principes 42:80-84.

Huber, J.T. 1986. Systematics, biology, and hosts of the Mymaridae and Mymarommatidae (Insecta: Hymenoptera): 1758-1984. Entomography 4:185-243

Kilpatrick, A.L., A.M. Hagerty, S.G. Turnipseed, M.J. Sullivan and W.C. Jr. Bridges. 2005. Activity of selected neonicotinoids and dicrotophos on nontarget arthropods in cotton: Implications in insect management. Journal of Economic Entomology 98:814-820.

Lawson, A.B., and D.L. Dahlsten. 2003. Evaluation of systemic insecticides as a treatment option in integrated pest management of the elm leaf beetle, Xanthogaleruca luteola (Müller) (Coleoptera: Chrysomelidae). Journal of Economic Entomology 96:1455-1462.

Lin, N-Q, J.T. Huber, and J. la Salle. 2007. The Australian genera of Mymaridae (Hymenoptera: Chalcidoidea). Zootaxa 1596:1-111.

McCulloch, C.E., and S.R. Searle. 2001. Generalized, Linear, and Mixed Models. John Wiley \& Sons, New York.

Noack, A.E., and H.A. Rose. 2007. Life-history of Thaumastocoris peregrinus and Thaumastocoris $\mathrm{sp}$. in the laboratory with some observations on behaviour. General and Applied Entomology 36:27-33.

Nauen, R. 1995. Behaviour modifying effects of low systemic concentrations of imidacloprid on Myzus persicae with special reference to an antifeeding response. Pesticide Science 44:145-153.

Nauen, R., U. Reckmann, S. Armborst, H.P. Strupp, and A. Elbert. 1999. Whitefly-active metabolites of imidacloprid: biological efficacy and translocation in cotton plants. Pesticide Science 55:265-271.

Oldroyd, B.P. 2007. What's killing American honey bees? PLoS Biol. 5 e168. doi:10.137/journal.pbio.0050168.

Patterson, H.D., and R. Thompson. 1971. Recovery of inter-block information when block sizes are unequal. Biometrika 58:545-554.

Poland, T.M., R.A. Haack, T.R. Petrice, D.L. Miller, L.S. Bauer, and R. Gao. 2006. Field evaluations of systemic insecticides for control of
Anoplophora glabripennis (Coleoptera: Cerambycidae) in China. Journal of Economic Entomology 99:383-392.

Reinert, J.A. 1975. Royal palm bug, Xylastodoris luteolus, damage and control on royal palms in Florida. P. Florida State Horticulture Society 88:591-593.

Smith, N.J., and D. Smith. 2000. Systemic insecticidal control of the flatid Jamella australiae Kirkaldy, a pest on Pandanus in southeast Queensland. General and Applied Entomology 29:21-25.

Szczepaniec, A., and M.J. Raupp. 2007. Residual toxicity of imidacloprid to hawthorn lace bug, Corythuca cydoniae, feeding on cotoneasters in landscapes and containers. Journal of Environmental Horticulture 25:43-46.

Webb, R.E., J.R. Frank, and M.J. Raupp. 2003. Eastern hemlock recovery from hemlock woolly adelgid damage following imidacloprid therapy. Journal Arboriculture 29:298-302.

Wingfield, M. 2007. From the Director's desk. Tree Protection News. Vol. 13. http://src.fabinet.up.ac.za/tpcp/newsletters/TPCP_May_2007.pdf. Last accessed 3 April 2008.

Young, L.C. 2002. The efficacy of micro-injected imidacloprid and oxydemeton-methyl on red gum eucalyptus trees, Eucalyptus camaldulensis, infested with red gum lerp psyllid, Glycaspis brimblecombei. Journal of Arboriculture 28:144-147.

Ann E. Noack (corresponding author)

Faculty of Agriculture, Food and Natural Resources

The University of Sydney, NSW, 2006, Australia

a.noack@usyd.edu.au

Jyri Kaapro

Bayer Environmental Science

30 Jakes Way, Wilton, NSW, 2571, Australia

Kathryn Bartimote-Aufflick

Institute for Teaching and Learning

The University of Sydney, NSW, 2006, Australia

Dr. Sarah Mansfield

Faculty of Agriculture, Food and Natural Resources

The University of Sydney, NSW, 2006, Australia

Harley A. Rose

Assoc Professor

Faculty of Agriculture, Food and Natural Resources

The University of Sydney, NSW, 2006, Australia 
Résumé. Le Thaumastocoris peregrinus, une espèce australienne, est un nouveau parasite problématique des eucalyptus plantés en milieu urbain à Sydney ainsi que dans les centres commerciaux de l'Australie. Au cours des dernières années, il s'est disséminé et il a atteint le statut de parasite problématique dans les plantations d'eucalyptus en Afrique du Sud et on l'a découvert plus récemment en Argentine et Uruguay. Les Eucalyptus scoparia matures en arbres de rues qui poussent dans la banlieue Sud de Sydney ont été micro-injectés avec de l'imidacloprid à trois concentrations différentes et ils ont été suivis durant trois ans. L'abondance de $T$. peregrinus chez les eucalyptus traités a décliné significativement comparativement aux arbres non traités durant cette période. De plus, à la plus faible concentration du produit chimique, cet insecte était effectivement sous contrôle pour une période de deux ans. L'imidacloprid (SilvaShield®; Bayer Environmental Science) a été homologué en Australie pour le contrôle de T. peregrinus.

Zusammenfassung. Thaumastocoris peregrinus ist ein in Australien beheimatetes Insekt und entwickelt sich zu einer neuen und ernstzunehmenden Pest für Eukalyptusbäume in Sydney, sowie in Kaufzentren in Australien. In wenigen Jahren hat es sich in südafrikanischen Eukalyptusplantagen ausgebreitet und Schädlingsstatus erlangt. Erst kürzlich wurde es in Argentinien und Uruguay entdeckt. Ausgewachsene Eukalyptus scoparia-Straßenbäume in den südlichen Randbereichen von Sydney wurden mit drei Konzentrationen von Imidacloprid injiziert und drei Jahre überwacht. Die Erscheinung von Th. peregrinus auf den behandelten Bäumen sank deutlich gegenüber den unbehandelten in diesem Zeitraum. Sogar mit der niedrigsten Konzentration der Chemikalie konnte das Insekt für zwei Jahre unter Kontrolle gehalten werden. Imidacloprid wurde in Australien zur Kontrolle von Th. peregrinus registriert.

Resumen. Thaumastocoris peregrinus, nativa de Australia, es una nueva y seria plaga de eucaliptos urbanos plantados en Sydney y centros comerciales de Australia. En años recientes, se ha dispersado y ha alcanzado plantaciones de eucalipto en Sur África y, más recientemente, se ha descubierto en Argentina y Uruguay. Árboles maduros de Eucalyptus scoparia, creciendo en un suburbio del sur de Sydney, se inyectaron con imidacloprid a tres concentraciones y se monitorearon por tres años. La abundancia de $T$. peregrinus en eucaliptos tratados declinó significativamente comparado con árboles no tratados. Además, a baja concentración del químico este insecto fue controlado efectivamente por dos años. Imidacloprid (SilvaShield®; Bayer Environmental Science) ha sido registrado en Australia para el control de T. peregrinus. 